\title{
Article \\ D-Amino Acid-Containing Lipopeptides Derived from the Lead Peptide BP100 with Activity against Plant Pathogens
}

\author{
Àngel Oliveras ${ }^{1}$, Luís Moll ${ }^{2}{ }^{(1)}$, Gerard Riesco-Llach ${ }^{1}$, Arnau Tolosa-Canudas ${ }^{1}$, Sergio Gil-Caballero ${ }^{3}$,

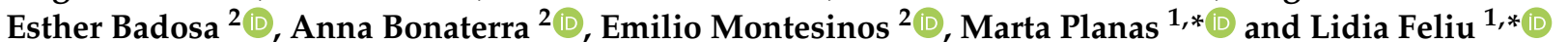

1 LIPPSO, Department of Chemistry, Campus Montilivi, University of Girona, 17004 Girona, Spain; a.oliveras.rovira@gmail.com (À.O.); gerard.riesco@udg.edu (G.R.-L.); arnauatc_11@hotmail.com (A.T.-C.)

2 Laboratory of Plant Pathology, Institute of Food and Agricultural Technology-CIDSAV-XaRTA, Campus Montilivi, University of Girona, 17004 Girona, Spain; lluismds@hotmail.com (L.M.); esther.badosa@udg.edu (E.B.); anna.bonaterra@udg.edu (A.B.); emilio.montesinos@udg.edu (E.M.)

3 Serveis Tècnics de Recerca (NMR), Universitat de Girona, Parc Científic i Tecnològic de la UdG, Pic de Peguera 15, 17004 Girona, Spain; sergio.gil@udg.edu

* Correspondence: marta.planas@udg.edu (M.P.); lidia.feliu@udg.edu (L.F.)

\section{check for} updates

Citation: Oliveras, À.; Moll, L.; Riesco-Llach, G.; Tolosa-Canudas, A.; Gil-Caballero, S.; Badosa, E.; Bonaterra, A.; Montesinos, E.; Planas, M.; Feliu, L. D-Amino Acid-Containing Lipopeptides Derived from the Lead Peptide BP100 with Activity against Plant Pathogens Int. J. Mol. Sci. 2021, 22, 6631. https://doi.org/10.3390/ijms22126631

Academic Editor: Ernest Giralt

Received: 28 May 2021

Accepted: 18 June 2021

Published: 21 June 2021

Publisher's Note: MDPI stays neutral with regard to jurisdictional claims in published maps and institutional affiliations.

Copyright: (C) 2021 by the authors. Licensee MDPI, Basel, Switzerland. This article is an open access article distributed under the terms and conditions of the Creative Commons Attribution (CC BY) license (https:// creativecommons.org/licenses/by/ $4.0 /$ )

\begin{abstract}
From a previous collection of lipopeptides derived from BP100, we selected 18 sequences in order to improve their biological profile. In particular, analogues containing a D-amino acid at position 4 were designed, prepared, and tested against plant pathogenic bacteria and fungi. The biological activity of these sequences was compared with that of the corresponding parent lipopeptides with all L-amino acids. In addition, the influence of the length of the hydrophobic chain on the biological activity was evaluated. Interestingly, the incorporation of a D-amino acid into lipopeptides bearing a butanoyl or a hexanoyl chain led to less hemolytic sequences and, in general, that were as active or more active than the corresponding all L-lipopeptides. The best lipopeptides were BP475 and BP485, both incorporating a D-Phe at position 4 and a butanoyl group, with MIC values between 0.8 and $6.2 \mu \mathrm{M}$, low hemolysis ( 0 and $24 \%$ at $250 \mu \mathrm{M}$, respectively), and low phytotoxicity. Characterization by NMR of the secondary structure of BP475 revealed that the D-Phe at position 4 disrupts the $\alpha$-helix and that residues 6 to 10 are able to fold in an $\alpha$-helix. This secondary structure would be responsible for the high antimicrobial activity and low hemolysis of this lipopeptide.
\end{abstract}

Keywords: acylation; hemolysis; secondary structure; NMR

\section{Introduction}

Agriculture is currently facing major challenges in terms of food production and conservation. It is expected that the world population will rise to more than 10 billion by 2100 according to the United Nations [1]. One of the main threats are plant diseases caused by bacteria and fungi that bring about important economic losses every year [2,3]. A strategy to overcome this problem relies on employing copper compounds, antibiotics, and fungicides. Even though these compounds are efficient, they are regarded as serious environmental contaminants and their use is restricted by the current regulations. For instance, antibiotics are banned in Europe because they prompt the appearance of resistant strains. Therefore, the development of safer compounds to fight these diseases is of paramount importance.

Antimicrobial peptides have received much attention as alternative pesticides [4-7]. They display a broad spectrum of activity and their mechanism of action generally involves the perturbation of the cell membrane which limits the induction of resistance [8-14]. Despite these excellent properties, research has been conducted to design new antimicrobial peptides with improved biological activity profiles [15-18]. Towards this end, a large number of synthetic lipopeptides have been described [19], mainly prompted by the 
presence of a fatty acid chain in many natural active peptides and by the essential role of this chain for their antimicrobial activity $[20,21]$. In fact, acylation is recognized as an effective peptide modification to increase antimicrobial activity and proteolytic stability [22-30]. The fatty acid chain confers lipophilicity, enhances the peptide ability to either adopt a specific secondary structure or oligomerize upon interacting with the bacterial membranes, and, therefore, facilitates the hydrophobic interaction between peptides and membranes [30].

One important limitation associated with antimicrobial lipopeptides that precludes their use is their low cell selectivity, probably due to their hydrophobicity, which results in high hemolytic activity [31]. A strategy to overcome this drawback is the incorporation of D-amino acids. This approach has been applied to antimicrobial peptides providing sequences that are not only less hemolytic, but also similarly active and more stable than their counterparts with all L-amino acids [32-41]. In previous studies on cyclic lipopeptides, we observed this trend when the residue bearing the fatty chain was replaced with its D-enantiomer [26]. The resulting cyclic lipopeptides with a D-amino acid were as active as their L-counterparts and, interestingly, they were not hemolytic at concentrations 10- to 80 -fold higher than their MIC values. Other studies have also shown that the combination of D-amino acids and a lipidic chain in a peptide constitutes an effective strategy to obtain sequences with improved biological activity [29,42-45].

In this context, we recently described a library of 36 lipopeptides derived from the linear antimicrobial undecapeptide H-Lys-Lys-Leu-Phe-Lys-Lys-Ile-Leu-Lys-Tyr-Leu- $\mathrm{NH}_{2}$ (BP100) [46]. These lipopeptides were designed by incorporating a butanoyl, hexanoyl or lauroyl chain at the N-terminus or at the side chain of a Lys residue. Lipopeptides with high antimicrobial activity and different degrees of hemolysis and phytotoxicity were identified. Taking into account the advantages of incorporating D-amino acids into the structure of lipopeptides, in the present work, we decided to evaluate the improvement of the biological profile of 18 selected lipopeptides through the replacement of one amino acid with its Denantiomer. Thus, we prepared these $18 \mathrm{D}$-amino acid-containing lipopeptides and tested their in vitro antimicrobial activity against six plant pathogenic bacteria and two plant pathogenic fungi as well as their hemolysis and phytotoxicity. Moreover, the secondary structure of one of the best D-amino acid-containing lipopeptides was characterized by NMR spectroscopy.

\section{Results}

\subsection{Design and Solid-Phase Synthesis of the Lipopeptides}

Taking into account the advantages of incorporating a D-amino acid into a peptide sequence, we selected a set of 18 lipopeptides derived from BP100, previously reported by our group [46], and replaced the amino acid at position 4 for the corresponding enantiomer. This position was chosen because in previous studies we had observed that the substitution of L-Phe ${ }^{4}$ in BP100 (H-Lys-Lys-Leu-Phe-Lys-Lys-Ile-Leu-Lys-Tyr-Leu- $\mathrm{NH}_{2}$ ) with a D-Phe resulted in peptide BP143 (H-Lys-Lys-Leu-D-Phe-Lys-Lys-Ile-Leu-Lys-Tyr-Leu$\mathrm{NH}_{2}$ ), which was more active and less hemolytic [32]. The selected lipopeptides displayed high activity but most of them were also highly hemolytic. Thus, the aim of this study was to obtain peptides with an improved biological activity profile. The sequence of the 18 lipopeptides bearing a D-amino acid is depicted in Table 1. 
Table 1. Sequences, retention times and purities on HPLC, and mass spectrometry data of lipopeptides.

\begin{tabular}{|c|c|c|c|c|c|c|c|}
\hline \multirow{2}{*}{ Peptide } & \multirow{2}{*}{ Sequence $^{1}$} & \multirow{2}{*}{ Code } & \multirow{2}{*}{$\underset{(\min )^{2}}{t_{R}}$} & \multirow{2}{*}{$\begin{array}{l}\text { Purity } \\
(\%)^{3}\end{array}$} & \multicolumn{3}{|c|}{ HRMS (ESI) } \\
\hline & & & & & & Calcd. & Found \\
\hline BP472 & $\mathrm{C}_{5} \mathrm{H}_{11} \mathrm{CO}-\mathrm{KKLfKKILKYL-NH} \mathrm{H}_{2}$ & $\mathrm{C}_{5} \mathrm{H}_{11} \mathrm{CO}-\mathrm{D}-\mathrm{F}^{4}$ & 6.14 & $>99$ & $\mathrm{C}_{78} \mathrm{H}_{137} \mathrm{~N}_{17} \mathrm{O}_{13}[\mathrm{M}+2 \mathrm{H}]^{2+}$ & 760.0285 & 760.0260 \\
\hline BP473 & Ac-KKLfKK $\left(\mathrm{COC}_{3} \mathrm{H}_{7}\right) \mathrm{ILKYL} \mathrm{NH}_{2}$ & $\mathrm{D}-\mathrm{F}^{4}-\mathrm{K}^{6}\left(\mathrm{COC}_{3} \mathrm{H}_{7}\right)$ & 5.99 & $>99$ & $\mathrm{C}_{78} \mathrm{H}_{135} \mathrm{~N}_{17} \mathrm{O}_{14}[\mathrm{M}+2 \mathrm{H}]^{2+}$ & 767.0182 & 767.0158 \\
\hline BP474 & Ac-KKLfKKIK $\left(\mathrm{COC}_{3} \mathrm{H}_{7}\right) \mathrm{KYL}-\mathrm{NH}_{2}$ & $\mathrm{D}-\mathrm{F}^{4}-\mathrm{K}^{8}\left(\mathrm{COC}_{3} \mathrm{H}_{7}\right)$ & 5.36 & $>99$ & $\mathrm{C}_{78} \mathrm{H}_{136} \mathrm{~N}_{18} \mathrm{O}_{14}[\mathrm{M}+2 \mathrm{H}]^{2+}$ & 774.5236 & 774.5208 \\
\hline BP475 & Ac-KKLfKKILKK $\left(\mathrm{COC}_{3} \mathrm{H}_{7}\right) \mathrm{L}-\mathrm{NH}_{2}$ & $\mathrm{D}-\mathrm{F}^{4}-\mathrm{K}^{10}\left(\mathrm{COC}_{3} \mathrm{H}_{7}\right)$ & 5.69 & $>99$ & $\mathrm{C}_{75} \mathrm{H}_{138} \mathrm{~N}_{18} \mathrm{O}_{13}[\mathrm{M}+2 \mathrm{H}]^{2+}$ & 749.5340 & 749.5343 \\
\hline BP476 & Ac-KKLfKKILKYK $\left(\mathrm{COC}_{11} \mathrm{H}_{23}\right)-\mathrm{NH}_{2}$ & $\mathrm{D}-\mathrm{F}^{4}-\mathrm{K}^{11}\left(\mathrm{COC}_{11} \mathrm{H}_{23}\right)$ & 6.67 & $>99$ & $\mathrm{C}_{86} \mathrm{H}_{152} \mathrm{~N}_{18} \mathrm{O}_{14}[\mathrm{M}+2 \mathrm{H}]^{2+}$ & 830.5862 & 830.5839 \\
\hline BP484 & Ac-KKLk $\left(\mathrm{COC}_{5} \mathrm{H}_{11}\right) \mathrm{KKILKYL} \mathrm{NH}_{2}$ & $\mathrm{D}-\mathrm{K}^{4}\left(\mathrm{COC}_{5} \mathrm{H}_{11}\right)$ & 6.45 & $>99$ & $\mathrm{C}_{77} \mathrm{H}_{142} \mathrm{~N}_{18} \mathrm{O}_{14}[\mathrm{M}+2 \mathrm{H}]^{2+}$ & 771.5471 & 771.5477 \\
\hline BP485 & $\mathrm{C}_{3} \mathrm{H}_{7} \mathrm{CO}-\mathrm{KKLfKKILKYL-NH}{ }_{2}$ & $\mathrm{C}_{3} \mathrm{H}_{7} \mathrm{CO}-\mathrm{D}-\mathrm{F}^{4}$ & 6.79 & $>99$ & $\mathrm{C}_{76} \mathrm{H}_{133} \mathrm{~N}_{17} \mathrm{O}_{13}[\mathrm{M}+2 \mathrm{H}]^{2+}$ & 746.0129 & 746.0097 \\
\hline BP486 & Ac-KK $\left(\mathrm{COC}_{3} \mathrm{H}_{7}\right)$ LfKKILKYL-NH $_{2}$ & $\mathrm{D}-\mathrm{F}^{4}-\mathrm{K}^{2}\left(\mathrm{COC}_{3} \mathrm{H}_{7}\right)$ & 6.17 & $>99$ & $\mathrm{C}_{78} \mathrm{H}_{134} \mathrm{~N}_{17} \mathrm{O}_{14}[\mathrm{M}+\mathrm{H}]^{+}$ & 1533.0291 & 1533.0266 \\
\hline BP488 & Ac-KKLk $\left(\mathrm{COC}_{11} \mathrm{H}_{23}\right){\mathrm{KKILKYL}-\mathrm{NH}_{2}}_{2}$ & $\mathrm{D}-\mathrm{K}^{4}\left(\mathrm{COC}_{11} \mathrm{H}_{23}\right)$ & 6.80 & $>99$ & $\mathrm{C}_{83} \mathrm{H}_{153} \mathrm{~N}_{18} \mathrm{O}_{14}[\mathrm{M}+\mathrm{H}]^{+}$ & 1626.1808 & 1626.1787 \\
\hline BP489 & Ac-KKLfKKK $\left(\mathrm{COC}_{11} \mathrm{H}_{23}\right)$ LKYL-NH $_{2}$ & $\mathrm{D}-\mathrm{F}^{4}-\mathrm{K}^{7}\left(\mathrm{COC}_{11} \mathrm{H}_{23}\right)$ & 6.76 & $>99$ & $\mathrm{C}_{86} \mathrm{H}_{152} \mathrm{~N}_{18} \mathrm{O}_{14}[\mathrm{M}+2 \mathrm{H}]^{2+}$ & 830.5862 & 830.5825 \\
\hline BP490 & Ac-KKLfKKIK $\left(\mathrm{COC}_{11} \mathrm{H}_{23}\right) \mathrm{KYL}_{-} \mathrm{NH}_{2}$ & $\mathrm{D}-\mathrm{F}^{4}-\mathrm{K}^{8}\left(\mathrm{COC}_{11} \mathrm{H}_{23}\right)$ & 7.12 & $>99$ & $\mathrm{C}_{86} \mathrm{H}_{151} \mathrm{~N}_{18} \mathrm{O}_{14}[\mathrm{M}+\mathrm{H}]^{+}$ & 1660.1652 & 1660.1635 \\
\hline BP494 & Ac-KKLfKKK $\left(\mathrm{COC}_{5} \mathrm{H}_{11}\right)$ LKYL-NH ${ }_{2}$ & $\mathrm{D}-\mathrm{F}^{4}-\mathrm{K}^{7}\left(\mathrm{COC}_{5} \mathrm{H}_{11}\right)$ & 5.42 & $>99$ & $\mathrm{C}_{80} \mathrm{H}_{139} \mathrm{~N}_{18} \mathrm{O}_{14}[\mathrm{M}+\mathrm{H}]^{+}$ & 1576.0713 & 1576.0683 \\
\hline BP495 & Ac-KKLfKKILKYK $\left(\mathrm{COC}_{5} \mathrm{H}_{11}\right)-\mathrm{NH}_{2}$ & $\mathrm{D}-\mathrm{F}^{4}-\mathrm{K}^{11}\left(\mathrm{COC}_{5} \mathrm{H}_{11}\right)$ & 5.44 & $>99$ & $\mathrm{C}_{80} \mathrm{H}_{139} \mathrm{~N}_{18} \mathrm{O}_{14}[\mathrm{M}+\mathrm{H}]^{+}$ & 1576.0713 & 1576.0683 \\
\hline BP496 & Ac-KKLfKKILKYK $\left(\mathrm{COC}_{3} \mathrm{H}_{7}\right)-\mathrm{NH}_{2}$ & $\mathrm{D}-\mathrm{F}^{4}-\mathrm{K}^{11}\left(\mathrm{COC}_{3} \mathrm{H}_{7}\right)$ & 5.11 & $>99$ & $\mathrm{C}_{78} \mathrm{H}_{135} \mathrm{~N}_{18} \mathrm{O}_{14}[\mathrm{M}+\mathrm{H}]^{+}$ & 1548.0400 & 1548.0367 \\
\hline BP497 & Ac-KKLfKKILK $\left(\mathrm{COC}_{11} \mathrm{H}_{23}\right)$ YL-NH ${ }_{2}$ & $\mathrm{D}-\mathrm{F}^{4}-\mathrm{K}^{9}\left(\mathrm{COC}_{11} \mathrm{H}_{23}\right)$ & 7.21 & $>99$ & $\mathrm{C}_{86} \mathrm{H}_{150} \mathrm{~N}_{17} \mathrm{O}_{14}[\mathrm{M}+\mathrm{H}]^{+}$ & 1645.1543 & 1645.1516 \\
\hline BP498 & Ac-KKLfK $\left(\mathrm{COC}_{3} \mathrm{H}_{7}\right) \mathrm{KILKYL} \mathrm{NH}_{2}$ & $\mathrm{D}-\mathrm{F}^{4}-\mathrm{K}^{5}\left(\mathrm{COC}_{3} \mathrm{H}_{7}\right)$ & 6.12 & $>99$ & $\mathrm{C}_{78} \mathrm{H}_{135} \mathrm{~N}_{17} \mathrm{O}_{14}[\mathrm{M}+2 \mathrm{H}]^{2+}$ & 767.0182 & 767.0147 \\
\hline BP499 & Ac-KKLfKKILK $\left(\mathrm{COC}_{3} \mathrm{H}_{7}\right)$ YL-NH & $\mathrm{D}-\mathrm{F}^{4}-\mathrm{K}^{9}\left(\mathrm{COC}_{3} \mathrm{H}_{7}\right)$ & 5.89 & $>99$ & $\mathrm{C}_{78} \mathrm{H}_{134} \mathrm{~N}_{17} \mathrm{O}_{14}[\mathrm{M}+\mathrm{H}]^{+}$ & 1533.0291 & 1533.0269 \\
\hline BP500 & Ac-KKK $\left(\mathrm{COC}_{11} \mathrm{H}_{23}\right)$ fKKILKYL-NH ${ }_{2}$ & $\mathrm{D}-\mathrm{F}^{4}-\mathrm{K}^{3}\left(\mathrm{COC}_{11} \mathrm{H}_{23}\right)$ & 6.80 & $>99$ & $\mathrm{C}_{86} \mathrm{H}_{151} \mathrm{~N}_{18} \mathrm{O}_{14}[\mathrm{M}+\mathrm{H}]^{+}$ & 1661.1684 & 1661.1667 \\
\hline
\end{tabular}

${ }^{1} \mathrm{COC}_{3} \mathrm{H}_{7}$, butanoyl; $\mathrm{COC}_{5} \mathrm{H}_{11}$, hexanoyl; $\mathrm{COC}_{11} \mathrm{H}_{23}$, lauroyl; lower case letters correspond to D-amino acids. ${ }^{2}$ HPLC retention time.

${ }^{3}$ Percentage determined by HPLC at $220 \mathrm{~nm}$ after purification.

These lipopeptides were synthesized on solid phase following a standard 9-fluorenylmethoxycarbonyl (Fmoc)/tert-butyl ( $t \mathrm{Bu})$ strategy as previously described [46]. A Fmoc-Rink-MBHA resin was used as solid support. In the case of lipopeptides incorporating a Lys residue acylated at the side chain, this amino acid was incorporated as Fmoc-Lys(ivDde)-OH or Fmoc-D-Lys(ivDde)-OH. After 1-(4,4-dimethyl-2,6-dioxocyclohex1-ylidine)-3-methylbutyl (ivDde) group removal, the $N^{\varepsilon}$-amino group was derivatized with butanoic, hexanoic or lauric acid. For the synthesis of BP472 and BP485 the N-terminus amino group was acylated with hexanoic and butanoic acid, respectively. Lipopeptides were cleaved from the support using trifluoroacetic acid (TFA) $/ \mathrm{H}_{2} \mathrm{O} /$ triisopropylsilane (TIS) and purified by reverse-phase column chromatography (HPLC). They were obtained in $>99 \%$ HPLC purity and their structure was verified by mass spectrometry (Table 1 ).

\subsection{Antimicrobial Activity}

Lipopeptides were screened for in vitro growth inhibition of the plant pathogenic bacteria Erwinia amylovora, Pseudomonas syringae pv. syringae, Pseudomonas syringae pv. actinidiae, Xanthomonas arboricola pv. pruni, Xanthomonas fragariae and Xanthomonas axonopodis pv. vesicatoria, and the plant pathogenic fungi Penicillium expansum and Fusarium oxysporum, at $0.8,1.6,3.1,6.2,12.5$ and $25 \mu \mathrm{M}$ (Figure 1, Table S1).

This set of 18 lipopeptides showed high antimicrobial activity (Figure 1). Concerning the antibacterial activity, 13 sequences exhibited MIC $<12.5 \mu \mathrm{M}$ against the six bacteria tested. The results showed that they were more active against the three Xanthomonas strains than against E. amylovora or the Pseudomonas species. Twelve lipopeptides displayed MIC < $6.2 \mu \mathrm{M}$ against the three Xanthomonas strains, among which nine showed MIC $<3.1 \mu \mathrm{M}$. Remarkably, an MIC between 0.8 and $1.6 \mu \mathrm{M}$ against one of these strains was observed for three sequences.

Regarding the Pseudomonas species, they displayed higher activity against $P$. syringae pv. actinidiae ( 15 sequences with MIC $<6.2 \mu \mathrm{M}$ ) than against $P$. syringae pv. syringae (10 sequences with MIC $<6.2 \mu \mathrm{M})$. Interestingly, five lipopeptides showed MIC between 1.6 and $3.1 \mu \mathrm{M}$ against $P$. syringae $\mathrm{pv}$. actinidiae. E. amylovora was the least sensitive bacterium towards these lipopeptides. However, 16 sequences exhibited MIC $<12.5 \mu \mathrm{M}$ with five of them showing MIC values between 3.1 and $6.2 \mu \mathrm{M}$. Regarding the influence of the fatty acid chain, no correlation was observed between the antibacterial activity and the length of this chain. However, those incorporating a lauroyl group were more active against the Xanthomonas strains. The lipopeptides with the highest antibacterial activity were BP472 $\left(\mathrm{C}_{5} \mathrm{H}_{11} \mathrm{CO}-\mathrm{D}-\mathrm{F}^{4}\right)$, BP473 $\left(\mathrm{D}-\mathrm{F}^{4}-\mathrm{K}^{6}\left(\mathrm{COC}_{3} \mathrm{H}_{7}\right)\right)$, BP475 $\left(\mathrm{D}^{-} \mathrm{F}^{4}-\mathrm{K}^{10}\left(\mathrm{COC}_{3} \mathrm{H}_{7}\right)\right)$, BP476 
(D-F $\left.\mathrm{F}^{4}-\mathrm{K}^{11}\left(\mathrm{COC}_{11} \mathrm{H}_{23}\right)\right)$, BP485 $\left(\mathrm{C}_{3} \mathrm{H}_{7} \mathrm{CO}-\mathrm{D}-\mathrm{F}^{4}\right)$, BP488 (D-K $\left.{ }^{4}\left(\mathrm{COC}_{11} \mathrm{H}_{23}\right)\right)$, and BP500 (D$\left.\mathrm{F}^{4}-\mathrm{K}^{3}\left(\mathrm{COC}_{11} \mathrm{H}_{23}\right)\right)$.

In the case of the antifungal activity, the lipopeptides were, in general, more active against F. oxysporum than against $P$. expansum (13 vs. 8 sequences with MIC $<6.2 \mu \mathrm{M}$, respectively) (Figure 1). Interestingly, MIC values between 0.8 and $1.6 \mu \mathrm{M}$ were observed for six and two sequences, respectively, which incorporate a butanoyl or a hexanoyl group. In particular, BP495 $\left(\mathrm{D}-\mathrm{F}^{4}-\mathrm{K}^{11}\left(\mathrm{COC}_{5} \mathrm{H}_{11}\right)\right)$, BP498 $\left(\mathrm{D}-\mathrm{F}^{4}-\mathrm{K}^{5}\left(\mathrm{COC}_{3} \mathrm{H}_{7}\right)\right)$ and $\mathbf{B P 4 9 9}\left(\mathrm{D}-\mathrm{F}^{4}\right.$ $\mathrm{K}^{9}\left(\mathrm{COC}_{3} \mathrm{H}_{7}\right)$ ) were the most active, with MIC between 0.8 and $3.1 \mu \mathrm{M}$ against both fungi.

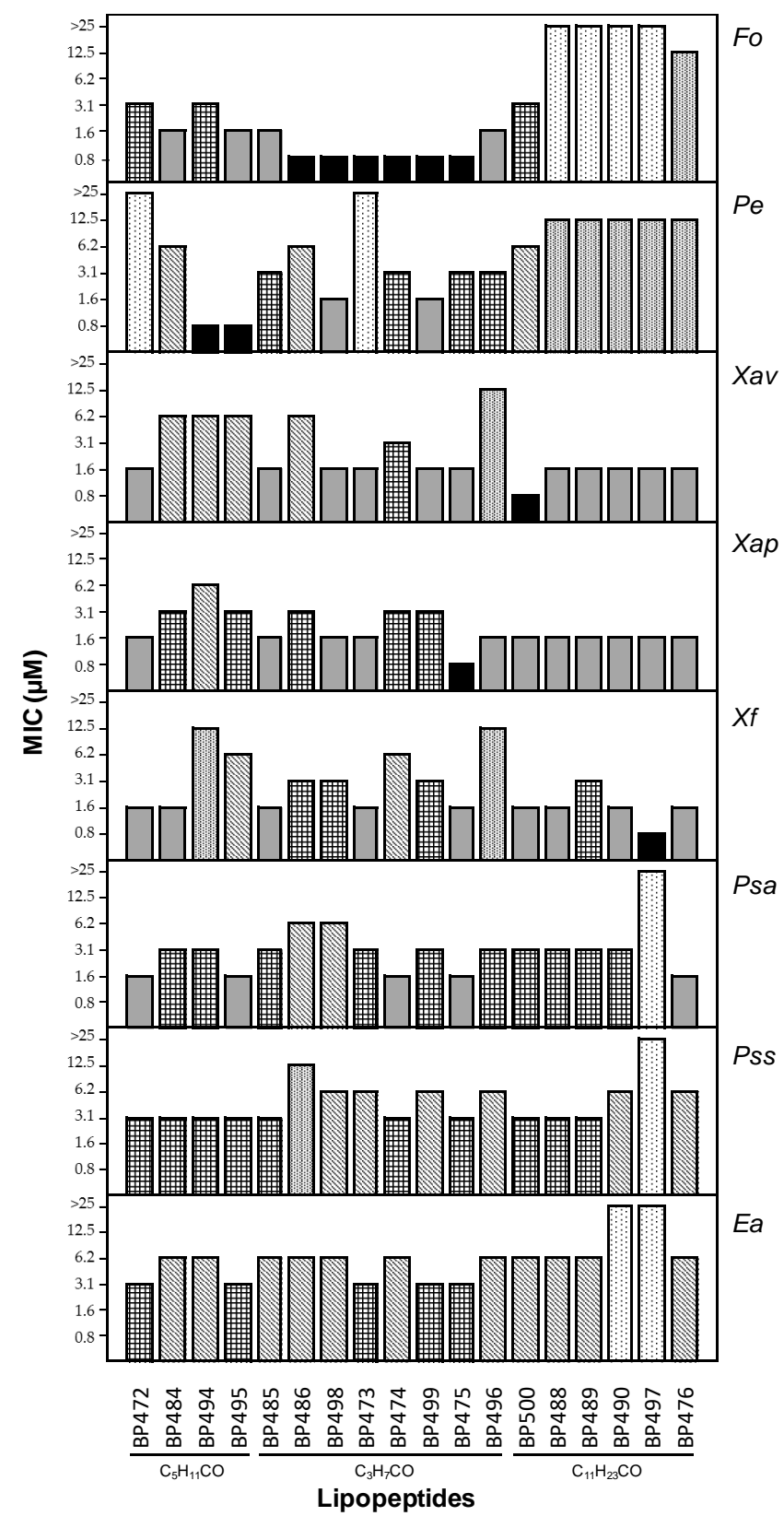

Figure 1. Antimicrobial activity of lipopeptides against the bacteria E. amylovora $(E a)$, P. syringae pv. syringae $\left(P_{s s}\right), P$. syringae pv. actinidiae $\left(P_{s a}\right), X$. fragariae $(X f), X$. arboricola pv. pruni $(X a p)$ and $X$. axonopodis pv. vesicatoria (Xav), and the fungi P. expansum (Pe) and F. oxysporum (Fo). The type of acyl group is indicated below the lipopeptides. Antimicrobial activity is given as the minimal concentration that inhibits growth (MIC). The MIC axis is in logarithmic scale, and for each sequence, the lowest values of the MIC range is represented. Data can be found in Table S1 (Supplementary Materials). 


\subsection{Toxicity}

The toxicity of lipopeptides to eukaryotic cells was determined as the ability to lyse erythrocytes in comparison to melittin, which was used as a reference peptide (Table 2 and Table S2). Lipopeptides were assayed at 50, 150, 250 and $375 \mu \mathrm{M}$. The results showed that 10 lipopeptides displayed $\leq 24 \%$ hemolysis at $250 \mu \mathrm{M}$. Among them, six sequences exhibited $\leq 10 \%$ hemolysis at this concentration, which incorporate either a butanoyl or a hexanoyl chain.

Table 2. Hemolytic activity and size of the lesion in infiltrated tobacco leaves of lipopeptides.

\begin{tabular}{|c|c|c|c|}
\hline Peptide & Code & $\begin{array}{c}\text { Hemolysis (\%) } \\
250 \mu \mathrm{M}\end{array}$ & $\begin{array}{c}\text { Size of the Lesion }(\mathrm{mm})^{2} \\
250 \mu \mathrm{M}\end{array}$ \\
\hline BP472 & $\mathrm{C}_{5} \mathrm{H}_{11} \mathrm{CO}-\mathrm{D}-\mathrm{F}^{4}$ & $78 \pm 5$ & $4 \pm 1$ \\
\hline BP473 & $\mathrm{D}-\mathrm{F}^{4}-\mathrm{K}^{6}\left(\mathrm{COC}_{3} \mathrm{H}_{7}\right)$ & $84 \pm 11$ & $5 \pm 2$ \\
\hline BP474 & $\mathrm{D}-\mathrm{F}^{4}-\mathrm{K}^{8}\left(\mathrm{COC}_{3} \mathrm{H}_{7}\right)$ & $0 \pm 0$ & $4 \pm 2$ \\
\hline BP475 & $\mathrm{D}-\mathrm{F}^{4}-\mathrm{K}^{10}\left(\mathrm{COC}_{3} \mathrm{H}_{7}\right)$ & $0 \pm 0$ & $10 \pm 1$ \\
\hline BP476 & $\mathrm{D}-\mathrm{F}^{4}-\mathrm{K}^{11}\left(\mathrm{COC}_{11} \mathrm{H}_{23}\right)$ & $94 \pm 10$ & $5 \pm 0.5$ \\
\hline BP484 & $\mathrm{D}-\mathrm{K}^{4}\left(\mathrm{COC}_{5} \mathrm{H}_{11}\right)$ & $10 \pm 2$ & $7 \pm 1$ \\
\hline BP485 & $\mathrm{C}_{3} \mathrm{H}_{7} \mathrm{CO}-\mathrm{D}-\mathrm{F}^{4}$ & $24 \pm 9$ & $12 \pm 1$ \\
\hline BP486 & $\mathrm{D}-\mathrm{F}^{4}-\mathrm{K}^{2}\left(\mathrm{COC}_{3} \mathrm{H}_{7}\right)$ & $14 \pm 5$ & $17 \pm 2$ \\
\hline BP488 & $\mathrm{D}-\mathrm{K}^{4}\left(\mathrm{COC}_{11} \mathrm{H}_{23}\right)$ & $86 \pm 14$ & $13 \pm 5$ \\
\hline BP489 & $\mathrm{D}-\mathrm{F}^{4}-\mathrm{K}^{7}\left(\mathrm{COC}_{11} \mathrm{H}_{23}\right)$ & $100 \pm 6$ & $11 \pm 1$ \\
\hline BP490 & $\mathrm{D}-\mathrm{F}^{4}-\mathrm{K}^{8}\left(\mathrm{COC}_{11} \mathrm{H}_{23}\right)$ & $100 \pm 6$ & $11 \pm 3$ \\
\hline BP494 & $\mathrm{D}-\mathrm{F}^{4}-\mathrm{K}^{7}\left(\mathrm{COC}_{5} \mathrm{H}_{11}\right)$ & $0.2 \pm 0.2$ & $8 \pm 1$ \\
\hline BP495 & $\mathrm{D}-\mathrm{F}^{4}-\mathrm{K}^{11}\left(\mathrm{COC}_{5} \mathrm{H}_{11}\right)$ & $0.6 \pm 1$ & $11 \pm 2$ \\
\hline BP496 & $\mathrm{D}-\mathrm{F}^{4}-\mathrm{K}^{11}\left(\mathrm{COC}_{3} \mathrm{H}_{7}\right)$ & $1 \pm 1$ & $10 \pm 3$ \\
\hline ВР497 & $\mathrm{D}-\mathrm{F}^{4}-\mathrm{K}^{9}\left(\mathrm{COC}_{11} \mathrm{H}_{23}\right)$ & $100 \pm 2$ & $18 \pm 0$ \\
\hline BP498 & $\mathrm{D}-\mathrm{F}^{4}-\mathrm{K}^{5}\left(\mathrm{COC}_{3} \mathrm{H}_{7}\right)$ & $21 \pm 3$ & $6 \pm 1$ \\
\hline BР499 & $\mathrm{D}-\mathrm{F}^{4}-\mathrm{K}^{9}\left(\mathrm{COC}_{3} \mathrm{H}_{7}\right)$ & $11 \pm 1$ & $8 \pm 2$ \\
\hline BP500 & $\mathrm{D}-\mathrm{F}^{4}-\mathrm{K}^{3}\left(\mathrm{COC}_{11} \mathrm{H}_{23}\right)$ & $71 \pm 8$ & $9 \pm 3$ \\
\hline
\end{tabular}

${ }^{1}$ Percent hemolysis plus confidence interval $(\alpha=0.05) .{ }^{2}$ Effect on the size of the lesion in infiltrated tobacco leaves plus confidence interval.

Lipopeptides were also assayed for their toxicity in tobacco leaves by infiltrating a solution of each peptide at 50,150 and $250 \mu \mathrm{M}$ into the mesophylls of the leaves (Table 2 and Table S3). For comparison purposes, melittin was also included in this experiment, causing a necrosis of $18 \mathrm{~mm}$ at $250 \mu \mathrm{M}$. Most lipopeptides were less toxic than melittin. In particular, 11 sequences caused a necrotic area $\leq 10 \mathrm{~mm}$ at $250 \mu \mathrm{M}$.

Interestingly, lipopeptides BP475 (D-F $\left.-\mathrm{K}^{10}\left(\mathrm{COC}_{3} \mathrm{H}_{7}\right)\right)$ and BP485 $\left(\mathrm{C}_{3} \mathrm{H}_{7} \mathrm{CO}-\mathrm{D}-\mathrm{F}^{4}\right)$, which displayed the highest antibacterial activity, and lipopeptides BP495 (D-F $-\mathrm{K}^{11}$ $\left.\left(\mathrm{COC}_{5} \mathrm{H}_{11}\right)\right)$, BP498 $\left(\mathrm{D}-\mathrm{F}^{4}-\mathrm{K}^{5}\left(\mathrm{COC}_{3} \mathrm{H}_{7}\right)\right)$ and $\mathbf{B P} 499\left(\mathrm{D}-\mathrm{F}^{4}-\mathrm{K}^{9}\left(\mathrm{COC}_{3} \mathrm{H}_{7}\right)\right)$ exhibiting high antifungal activity were also low toxic at concentrations around the MIC.

\subsection{Structural Characterization by NMR Spectroscopy}

The structure of lipopeptide BP475 (D-F $\left.\mathrm{F}^{4}-\mathrm{K}^{10}\left(\mathrm{COC}_{3} \mathrm{H}_{7}\right)\right)$, which displayed high antimicrobial activity, was characterized by ${ }^{1} \mathrm{H},{ }^{1} \mathrm{H}_{-}{ }^{13} \mathrm{C}$ and ${ }^{1} \mathrm{H}-{ }^{15} \mathrm{~N}-\mathrm{NMR}$. In order to evaluate the influence of incorporating the D-amino acid, its analog with all $\mathrm{L}$-amino acids AcKKLFKKILKK $\left(\mathrm{COC}_{3} \mathrm{H}_{7}\right) \mathrm{L}^{-\mathrm{NH}_{2}}$ (BP389) was included in this study.

1D ${ }^{1} \mathrm{H}-\mathrm{NMR}$ and 2D ${ }^{1} \mathrm{H}_{-}{ }^{1} \mathrm{H}$ TOCSY, 2D ${ }^{1} \mathrm{H}_{-}{ }^{13} \mathrm{C}$ HSQC, 2D ${ }^{1} \mathrm{H}_{-}{ }^{15} \mathrm{~N}$ HSQC and ${ }^{1} \mathrm{H}-$ ${ }^{1} \mathrm{H}$ NOESY spectra were first recorded at $10{ }^{\circ} \mathrm{C}$ in phosphate buffer at $\mathrm{pH}=6.5$ in $\mathrm{H}_{2} \mathrm{O} / \mathrm{D}_{2} \mathrm{O}$ (9:1). These experiments allowed the assignment of the ${ }^{1} \mathrm{H},{ }^{13} \mathrm{C}$ and ${ }^{15} \mathrm{~N}$ signals (Tables S4-S7). $1 \mathrm{D}^{1} \mathrm{H}$ and $2 \mathrm{D}^{1} \mathrm{H}_{-}{ }^{1} \mathrm{H}$ NOESY experiments revealed that these two lipopeptides are completely unstructured in these conditions (Figure 2). 
(a)

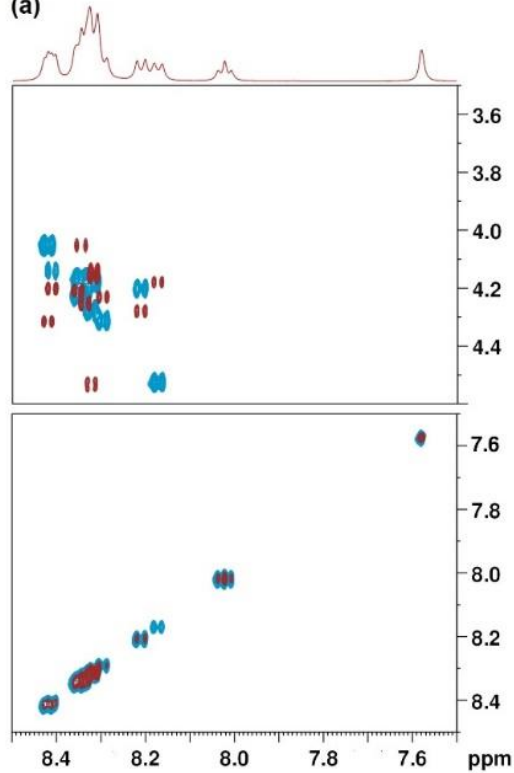

(c)

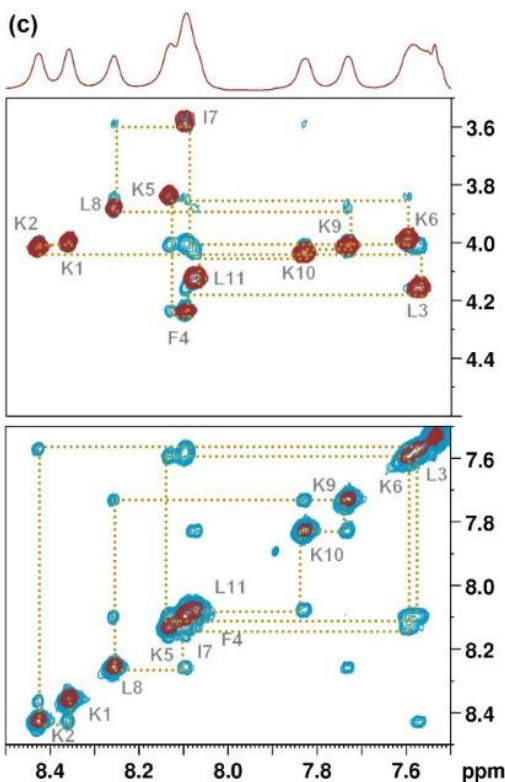

(b)

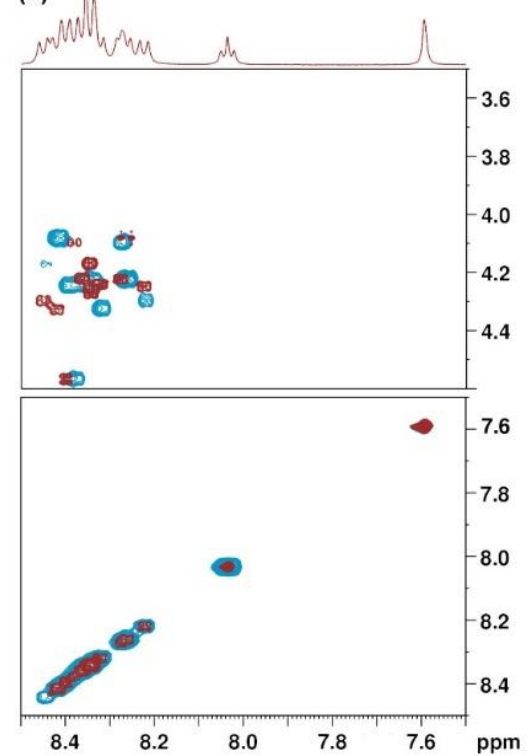

(d)

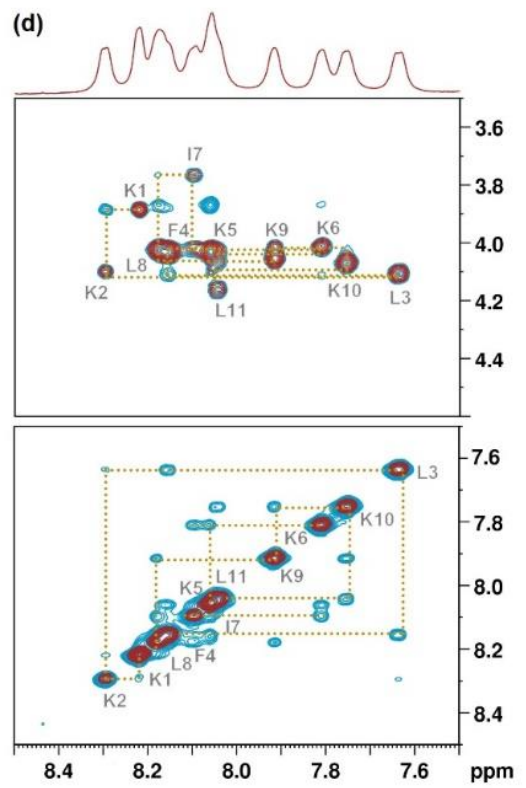

Figure 2. Overlay of $\mathrm{HN}-\mathrm{HN}$ and $\mathrm{HN}-\mathrm{H} \alpha$ TOCSY (red) and NOESY (blue) correlations for (a) BP389 and (b) BP475 in phosphate buffer; (c) BP389 and (d) BP475 in phosphate buffer with $30 \% \mathrm{CF}_{3} \mathrm{CD}_{2} \mathrm{OD}$.

Next, the above experiments were conducted in the presence of $30 \% \mathrm{CF}_{3} \mathrm{CD}_{2} \mathrm{OD}$ [47]. After the assignment of all the ${ }^{1} \mathrm{H},{ }^{13} \mathrm{C}$ and ${ }^{15} \mathrm{~N}$ signals, the primary structure of the peptides was confirmed based on the NOE correlation in the $\mathrm{HN}-\mathrm{H} \alpha$ fingerprint region (Figure 2). Compared to the spectra recorded in $\mathrm{H}_{2} \mathrm{O} / \mathrm{D}_{2} \mathrm{O}(9: 1)$, in this case, all the HN-H $\alpha$ crosspeaks could be unambiguously assigned and the analysis of the NOESY showed sequential correlations between amide protons. In addition, the "sequential walk" was achieved with the combination of NOESY $\mathrm{H} \alpha_{(\mathrm{i})}-\mathrm{HN}_{(\mathrm{i}+1)}$ inter-residue correlations and TOCSY $\mathrm{H} \alpha_{(\mathrm{i})}-\mathrm{HN}_{(\mathrm{i})}$ intra-residue correlations. All these results pointed out that these lipopeptides adopt a secondary structure in the presence of $\mathrm{CF}_{3} \mathrm{CD}_{2} \mathrm{OD}$.

Subsequent chemical shift index analysis was employed to identify the secondary structure of these lipopeptides (Figure 3). It was observed that while residues 2 to 10 in BP389 form $\alpha$-helical structure, in BP475, only residues 6 to 10 adopt this conformation. The disruption of the $\alpha$-helix in BP475 could be attributed to the presence of a D-Phe at position 4 . 

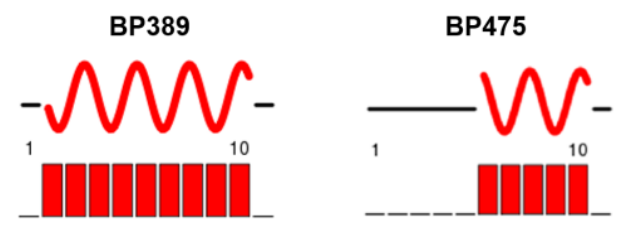

Figure 3. Secondary structure adopted by each peptide. Numbers indicate the position of the amino acids. The red curve represents an $\alpha$-helix, while the black line stands for a random coil region.

\section{Discussion}

Lipopeptides are a subfamily of antimicrobial peptides that have attracted attention due to their biological activity $[20,23,24,27]$. However, their use has been hampered by the high hemolysis that they generally display. One strategy to address this issue is the incorporation of a D-amino acid in their sequence [32-37,39,48]. In fact, natural lipopeptides bearing D-amino acids with an interesting biological activity profile have been reported, such as polymyxins, daptomycin, surfactins, iturins and fengycins [20,24,27]. In addition, synthetic D,L-amino acid-containing lipododecapeptides and ultrashort lipopeptides with high antimicrobial activity have also been described [22,42,49]. Moreover, in a previous study on cyclic lipopeptides, we observed that the replacement of an L-amino acid by its D-enantiomer led to sequences with lower hemolysis and similar antimicrobial activity [26]. Based on these reports, in this work, we describe 18 lipopeptides derived from the lead peptide BP100 containing a D-amino acid with activity against plant pathogenic bacteria and fungi.

These 18 D-amino acid-containing lipopeptides displayed high antimicrobial activity against the pathogens tested (13 sequences with MIC $<12.5 \mu \mathrm{M}$ against at least six pathogens). In general, the highest activity was observed against Xanthomonas strains and F. oxysporum. The length of the hydrophobic chain influenced the antimicrobial activity. Whereas lipopeptides bearing a butanoyl or a hexanoyl group were active against all bacteria and fungi, those incorporating a lauroyl group displayed high activity mainly against Xanthomonas species. These results and those obtained for lipopeptides with all L-amino acids [46] differed from the general trend described for the antimicrobial activity of lipopeptides [19,22,23,42,49-52]. The presence of a long acyl chain is, in general, related to high antimicrobial activity. In the present work, lipopeptides containing a lauroyl group were poorly active against fungi and, in contrast, an acyl chain of four and six carbons endowed these compounds with activity.

The length of the fatty acid also influenced the cytotoxicity against red blood cells. Lipopeptides incorporating a butanoyl or a hexanoyl group were, in general, low hemolytic, those with a 12-carbon atom lauroyl group being the ones with the highest hemolysis. The presence of a long fatty acid chain has been associated with a high cytotoxicity due to an increase of peptide hydrophobicity, which in turn results in a high erythrocyte membrane affinity $[26,53,54]$. In contrast, in the case of the effect of lipopeptides on the size of the lesion in infiltrated tobacco leaves, no correlation between the length of the hydrophobic chain and this effect was observed. All lipopeptides were less phytotoxic than melittin at $250 \mu \mathrm{M}$, concentration generally between 20 and 156-fold higher than the MIC. Similar results have been described for other lipopeptides, such as cyclolipopeptides and ultrashort cationic lipopeptides [26,55].

The biological activity of the D-amino acid-containing lipopeptides was compared to that of the corresponding parent lipopeptides with all L-amino acids [46] in order to analyse the influence of incorporating a D-amino acid (Figures 4-6). Regarding the antimicrobial activity, a different trend was observed depending on the fatty acid length (Figure 4). In the case of the lauroyl derivatives, the antimicrobial activity was maintained or improved against all the pathogens, except for F. oxysporum. The lipopeptides bearing a D-amino acid and a butanoyl or a hexanoyl chain were similarly active or even more active than the corresponding all L-lipopeptides against the two Pseudomonas species, X. arboricola pv. pruni and the two fungi. As expected, the incorporation of a D-amino acid resulted 
in a decrease of the hemolysis for all peptides bearing a butanoyl or a hexanoyl moiety (Figure 5). Remarkably, in some cases, this decrease was considerable. In contrast, the hemolysis did not improve for peptides incorporating a lauroyl group. Probably, the benefit of incorporating of a D-amino acid was not able to counteract the hydrophobicity of a 12-carbon atom lauroyl group. Concerning the phytotoxicity, a smaller size of the lesion compared to that of the L-lipopeptides was observed for the sequences bearing a butanoyl or a hexanoyl moiety (Figure 6).



Figure 4. Antimicrobial activity of lipopeptides incorporating all L-amino acids or a D-amino acid against E. amylovora (Ea), P. syringae pv. syringae (Pss), P. syringae pv. actinidiae $(P s a), X$. fragariae $(X f), X$. arboricola pv. pruni (Xap) and X. axonopodis pv. vesicatoria (Xav), and the fungi P. expansum ( $P e$ ) and F. oxysporum ( $F o$ ). The $\mathrm{x}$ axis includes the code for each lipopeptide. The residue that can be a L- or a D-amino acid is indicated in italics. Antimicrobial activity is given as the minimal concentration that inhibits growth (MIC). The MIC axis is in logarithmic scale and for each sequence the lowest values of the MIC range is represented. Black symbols correspond to the activity of lipopeptides with a D-amino acid, white symbols to the activity of lipopeptides with all L-amino acids, and grey symbols indicate that both lipopeptides display the same activity. Data can be found in Table S1 (Supplementary Materials). 


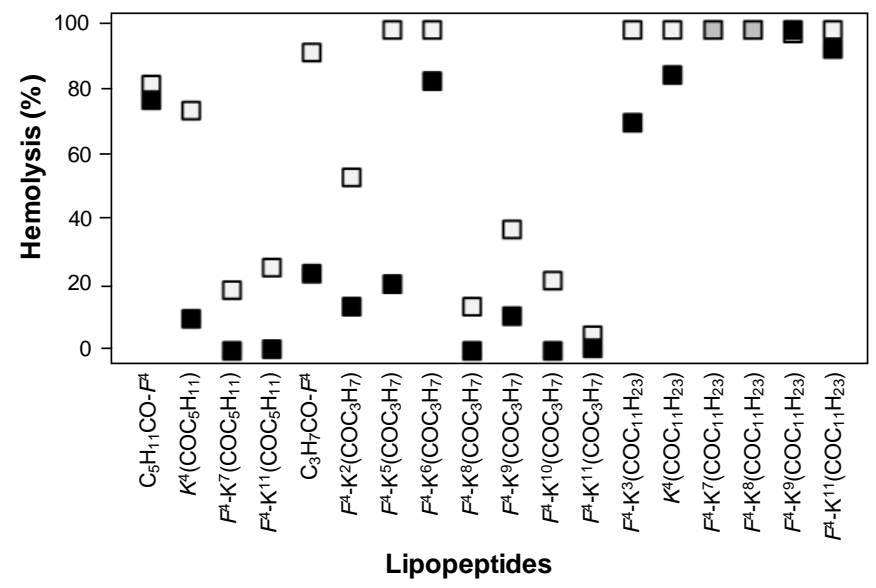

Figure 5. Hemolytic activity of the lipopeptides incorporating all L-amino acids or a D-amino acid. The $\mathrm{x}$ axis includes the code for each lipopeptide. The residue that can be an L- or a D-amino acid is indicated in italics. Hemolytic activity was measured at $250 \mu \mathrm{M}$ and is expressed as a percentage compared to melittin as a standard. Black squares correspond to the hemolysis of lipopeptides with a D-amino acid, white squares to the hemolysis of lipopeptides with all L-amino acids, and grey squares indicate that both lipopeptides display the same hemolysis. Data can be found in Table S2 (Supplementary Materials).

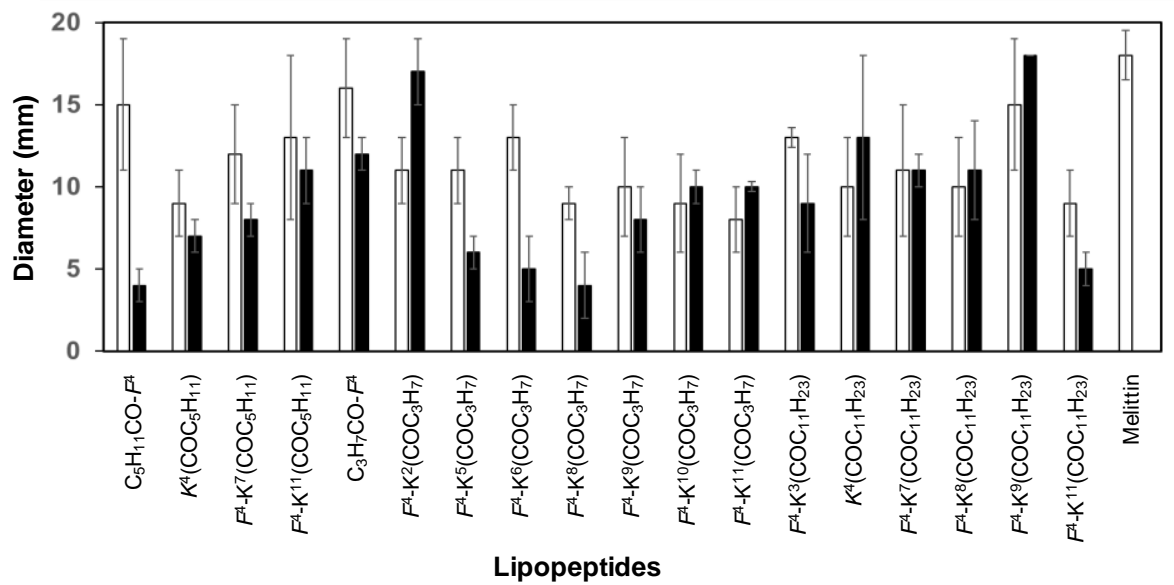

Figure 6. Effect of the lipopeptides incorporating all L-amino acids or a D-amino acid on the size of the lesions in infiltrated tobacco leaves at $250 \mu \mathrm{M}$. This effect was compared to melittin. Vertical bars within each column indicate confidence interval at the mean. The $\mathrm{x}$ axis includes the code for each lipopeptide. The residue that can be a L- or a D-amino acid is indicated in italics. Black bars correspond to lipopeptides with a D-amino acid and white bars to lipopeptides with all L-amino acids. Data can be found in Table S3 (Supplementary Materials).

All these results led us to identify BP475 (D-F $-\mathrm{K}^{10}\left(\mathrm{COC}_{3} \mathrm{H}_{7}\right)$ and BP485 $\left(\mathrm{C}_{3} \mathrm{H}_{7} \mathrm{CO}-\mathrm{D}\right.$ $\mathrm{F}^{4}$ ) as the D-amino acid containing lipopeptides with the best biological activity profile. Both sequences contain a butanoyl group and a D-Phe at position 4 . These peptides exhibited MIC values between 0.8 and $6.2 \mu \mathrm{M}$ against 7 out of the 8 pathogens tested, were significantly less hemolytic ( 0 and $24 \%$ at $250 \mu \mathrm{M}$, respectively) than the corresponding allL derivatives (22 and $93 \%$ at $250 \mu \mathrm{M}$, respectively), and were low phytotoxic. Interestingly, these lipopeptides are comparable in terms of activity to antibiotics used in agriculture for bacterial disease control, such as streptomycin, which is effective in vitro at 2 to $9 \mu \mathrm{M}$.

Characterization by NMR of the secondary structure of BP475 in the presence of $\mathrm{CF}_{3} \mathrm{CD}_{2} \mathrm{OD}$ evidenced that, as expected, the D-Phe at position 4 disrupts the $\alpha$-helix, whereas the incorporation of an acyl lysine at position 10 has no effect. Accordingly, 
chemical shift index analysis pointed out that residues 6 to 10 of this lipopeptide fold into an $\alpha$-helix. In contrast, the whole sequence of the L-Phe-containing analog BP389 adopts an $\alpha$-helical structure. The high antimicrobial activity displayed by these two lipopeptides stresses the importance of the C-terminal $\alpha$-helix in this activity. These results are in accordance with the carpet mechanism reported for the parent peptide BP100, which involves the insertion of its C-terminus into the hydrophobic core of the bilayer, resulting in membrane permeabilization [56]. Assuming a similar mechanism for lipopeptides BP389 and BP475, the presence of the acyl group in the C-terminal $\alpha$-helix region would favour their insertion into the membrane, thereby leading to a higher antimicrobial activity than BP100. Regarding the hemolysis, the disruption of the $\alpha$-helical structure of BP475 due to the presence of the D-Phe could explain the low hemolytic activity displayed by this peptide compared to its L-counterpart BP389, which is in agreement with previous reports [33].

\section{Materials and Methods}

\subsection{General Methods}

Manual peptide synthesis was performed in polypropylene syringes (2 or $5 \mathrm{~mL}$ ) fitted with a porous polyethylene disk. Solvents and soluble reagents were removed by suction. Most chemicals were purchased from commercial suppliers Merck (Madrid, Spain), Iris Biotech GmbH (Marktredwitz, Germany), Scharlab (Sentmenat, Spain), Carlo Erba Reagents (Sabadell, Spain) or Panreac (Castellar del Vallès, Spain), and used without further purification.

Peptides were analyzed under standard analytical HPLC conditions with a Dionex liquid chromatography instrument composed of a UV/Vis Dionex UVD170U detector, a P680 Dionex pump, an ASI-100 Dionex automatic injector, and CHROMELEON 6.60 software. Detection was performed at a wavelength of $220 \mathrm{~nm}$. Solvent A was $0.1 \%$ aqueous TFA and solvent $\mathrm{B}$ was $0.1 \%$ TFA in $\mathrm{CH}_{3} \mathrm{CN}$. Analyses were carried out with a Kromasil $100 \mathrm{C}_{18}(4.6 \mathrm{~mm} \times 40 \mathrm{~mm}, 3 \mu \mathrm{m})$ column with a linear gradient of 2 to $100 \%$ B over 7 $\mathrm{min}$ at a flow rate of $1 \mathrm{~mL} / \mathrm{min}$. Peptides were also analysed with a 1260 Infinity II liquid chromatography instrument (Agilent Technologies) composed of a Diode Array Detector HS, a Quaternary Pump VL, a 1260 Vial sampler and OpenLab CDS ChemStation software. Analyses were carried out with a Kromasil $100 \mathrm{C}_{18}(4.6 \mathrm{~mm} \times 40 \mathrm{~mm}, 3 \mu \mathrm{m})$ column with a linear gradient of 2 to $100 \%$ B over $12 \mathrm{~min}$ at a flow rate of $1 \mathrm{~mL} / \mathrm{min}$.

All purifications were performed on a CombiFlash Rf200 automated flash chromatography system using RediSep Rf Gold reversed-phase column packed with high performance $\mathrm{C}_{18}$ derivatized silica.

ESI-MS analyses were performed at the Serveis Tècnics de Recerca of the University of Girona with an Esquire 6000 ESI ion Trap LC/MS (Bruker Daltonics) instrument equipped with an electrospray ion source. The instrument was operated in the positive ESI(+) ion mode. Samples $(5 \mu \mathrm{L})$ were introduced into the mass spectrometer ion source directly through an HPLC autosampler. The mobile phase $\left(80: 20 \mathrm{CH}_{3} \mathrm{CN} / \mathrm{H}_{2} \mathrm{O}\right.$ at a flow rate of $100 \mu \mathrm{L} / \mathrm{min}$ ) was delivered by a 1200 Series HPLC pump (Agilent). Nitrogen was employed as both the drying and nebulising gas.

HRMS were recorded on a Bruker MicroTof-QIITM instrument using ESI ionization source at the Serveis Tècnics de Recerca of the University of Girona. Samples were introduced into the mass spectrometer ion source by direct infusion using a syringe pump and were externally calibrated using sodium formate. The instrument was operated in the positive ion mode.

\subsection{Synthesis of Lipopeptides}

These lipopeptides were synthesized manually by the solid-phase method using standard Fmoc chemistry as described previously [46]. The Fmoc-Rink-MBHA resin $(0.56 \mathrm{mmol} / \mathrm{g})$ was used as a solid support. Fmoc-Leu-OH, Fmoc-Lys(Boc)-OH, FmocLys(ivDde)-OH, Fmoc-D-Lys(ivDde)-OH, Fmoc-Phe-OH, Fmoc-Ile-OH, Fmoc-D-Phe-OH 
and Fmoc-Tyr $(t \mathrm{Bu})-\mathrm{OH}$ were used as amino acid derivatives. Peptide elongation was carried out through sequential Fmoc removal and coupling of the corresponding amino acid. Fmoc group removal was achieved with piperidine $/ N, N$-dimethylformamide (DMF) $(3: 7,2+10 \mathrm{~min})$. Couplings of the Fmoc-amino acids (4 equiv.) were mediated by ethyl 2-ciano-2-(hydroxyimino)acetate (Oxyma) (4 equiv.) and $N, N^{\prime}$-diisopropylcarbodiimide (DIC) (4 equiv.) in DMF at room temperature for $1 \mathrm{~h}$ under stirring. The completion of the reactions was checked with the Kaiser test [57]. After each coupling and deprotection step, the resin was washed with $\mathrm{DMF}(6 \times 1 \mathrm{~min})$ and $\mathrm{CH}_{2} \mathrm{Cl}_{2}(2 \times 1 \mathrm{~min})$. Once the peptide elongation was completed, the peptidyl resin was treated with piperidine/ $\mathrm{N}$-methyl-2pyrrolidinone (NMP) $(3: 7,2+10 \mathrm{~min})$, washed with $\mathrm{NMP}(6 \times 1 \mathrm{~min})$, and $\mathrm{CH}_{2} \mathrm{Cl}_{2}(2 \times$ $1 \mathrm{~min})$, and air dried.

For lipopeptides BP472 and BP485, the N-terminal deprotected resin was acylated by treatment with the corresponding fatty acid ( 3 equiv.), DIC (3 equiv.) and Oxyma (3 equiv.) in NMP under stirring overnight. After this time, the resin was washed with NMP $(6 \times$ $1 \mathrm{~min})$ and $\mathrm{CH}_{2} \mathrm{Cl}_{2}(6 \times 1 \mathrm{~min})$, and air dried. Completion of the reaction was checked with the Kaiser test [57].

In the case of the side chain acylated derivatives, the $\mathrm{N}$-terminal deprotected resin was acetylated with acetic anhydride $\left(\mathrm{Ac}_{2} \mathrm{O}\right) /$ pyridine $/ \mathrm{CH}_{2} \mathrm{Cl}_{2}(1: 1: 1 ; 2 \times 30 \mathrm{~min})$, washed with $\mathrm{NMP}(6 \times 1 \mathrm{~min})$ and $\mathrm{CH}_{2} \mathrm{Cl}_{2}(6 \times 1 \mathrm{~min})$, and air dried. Completion of the reaction was checked with the Kaiser test [57]. The resulting resin was treated with $\mathrm{NH}_{2} \mathrm{NH}_{2} \cdot \mathrm{H}_{2} \mathrm{O} / \mathrm{NMP}$ $(2: 98,10 \times 20 \mathrm{~min})$ under stirring and washed with $\mathrm{NMP}(2 \times 1 \mathrm{~min}), \mathrm{CH}_{2} \mathrm{Cl}_{2}(2 \times 1 \mathrm{~min})$, $\mathrm{MeOH}(2 \times 1 \mathrm{~min})$, and NMP $(2 \times 1 \mathrm{~min})$. Then, the resin was acylated by treatment with the corresponding fatty acid ( 3 equiv.), DIC ( 3 equiv.) and Oxyma ( 3 equiv.) in NMP under stirring overnight. The resin was then washed with NMP $(6 \times 1 \mathrm{~min})$ and $\mathrm{CH}_{2} \mathrm{Cl}_{2}(6 \times$ $1 \mathrm{~min})$, and air dried. Completion of the reaction was checked with the Kaiser test [57].

Finally, each resulting peptidyl resin was treated with TFA/ $\mathrm{H}_{2} \mathrm{O} / \mathrm{TIS}$ (95:2.5:2.5) for $2 \mathrm{~h}$. Following TFA evaporation and diethyl ether extraction, the crude lipopeptide was purified by reverse-phase column chromatography, lyophilized, analysed by HPLC, and characterized by mass spectrometry.

\subsection{Bacterial and Fungal Strains and Growth Conditions}

The following plant pathogenic bacterial strains were used: Erwinia amylovora PMV6076 (Institut National de la Recherche Agronomique, Angers, France), Pseudomonas syringae pv. syringae EPS94 (Institut de Tecnologia Agroalimentària, University of Girona, Spain), Xanthomonas axonopodis pv. vesicatoria 2133-2, Pseudomonas syringae pv. actinidiae Psa3700.1.1, Xanthomonas fragariae Xf349-9A (Instituto Valenciano de Investigaciones Agrarias, Valencia, Spain), and Xanthomonas arboricola pv. pruni CFBP5563 (Collection Française de Bactéries Associées aux Plantes, Angers, France). All bacteria except for X. fragariae were stored in Luria Bertani (LB) broth supplemented with glycerol $(20 \%)$ and maintained at $-80{ }^{\circ} \mathrm{C}$. For $X$. fragariae, Medium B [58] was used instead of LB. E. amylovora, X. arboricola pv. pruni, $P$. syringae pv. syringae and P. syringae pv. actinidiae were scrapped from the agar media after growing for $24 \mathrm{~h}$ at $25^{\circ} \mathrm{C}$, and X. axonopodis pv. vesicatoria and X. fragariae after growing for $48 \mathrm{~h}$ at $25^{\circ} \mathrm{C}$. The cell material was suspended in sterile water to obtain a suspension of $10^{8} \mathrm{CFU} \mathrm{mL} \mathrm{mL}^{-1}$. The following plant pathogenic fungal strains were used: Penicillium expansum EPS26 (Institut de Tecnologia Agroalimentària, University of Girona, Spain) and Fusarium oxysporum f. sp. lycopersici FOL 3 race 2 (ATCC 201829, American Type Culture Collection, Virginia, EEUU). Strains were cultured on potato dextrose agar (PDA) plates (Difco). Conidia from P. expansum and microconidia from F. oxysporum were obtained from five- to seven-day-old PDA cultures after growth at $25^{\circ} \mathrm{C}$. Inoculum was prepared by scraping spore material from culture surfaces with a cotton swab and resuspending it in distilled water containing $0.5 \%$ of tween 80 . The suspensions were filtered through Miracloth (Merk, Millipore) and the concentration of conidia was determined using a hemacytometer and adjusted to $10^{4}$ conidia $\mathrm{mL}^{-1}$ for . oxysporum and to $10^{3}$ conidia $\mathrm{mL}^{-1}$ for P. expansum. 


\subsection{Antimicrobial Activity}

Lyophilized peptides were solubilized in sterile Milli-Q water to a final concentration of $1 \mathrm{mM}$ and filter sterilized through a $0.22-\mu \mathrm{m}$ pore filter. For minimum inhibitory concentration (MIC) assessment, dilutions of the compounds were made to obtain a stock concentration of 250, 125, 62, 31, 16, 8 and $4 \mu \mathrm{M}$. For antibacterial activity, $20 \mu \mathrm{L}$ of each dilution were mixed in a microtiter plate well with $20 \mu \mathrm{L}$ of the corresponding suspension of the bacterial indicator, $160 \mu \mathrm{L}$ of trypticase soy broth (TSB) (BioMèrieux, France) to a total volume of $200 \mu \mathrm{L}$. For antifungal activity, $20 \mu \mathrm{L}$ of each stock solution were mixed in a microtiter plate well with $80 \mu \mathrm{L}$ of the corresponding suspension of the fungal pathogen and $100 \mu \mathrm{L}$ of double concentrated potato dextrose broth (PDB) to a total volume of $200 \mu \mathrm{L}$ containing $0.003 \% \mathrm{w} / \mathrm{v}$ of chloramphenicol to prevent bacterial contamination. Three replicates for each combination of strain, compound and concentration were used.

Microbial growth was determined by optical density measurement at $600 \mathrm{~nm}$ (Bioscreen C, Labsystem, Helsinki, Finland). For antibacterial activity, microplates were incubated at $25^{\circ} \mathrm{C}$ with $10 \mathrm{~s}$ shaking before hourly absorbance measurement for $48 \mathrm{~h}$. For antifungal activity, microplates were incubated at $22{ }^{\circ} \mathrm{C}$ with 1 min shaking before absorbance measurement carried out every $2 \mathrm{~h}$ for seven days. The experiment was repeated twice. The MIC was taken as the lowest compound concentration with no growth at the end of the experiment.

\subsection{Hemolytic Activity}

The hemolytic activity of the compounds was evaluated by determining hemoglobin release from erythrocyte suspensions of horse blood ( $5 \% \mathrm{vol} / \mathrm{vol}$ ) (Oxoid) as previously described [59]. Blood was centrifuged at $6000 \mathrm{~g}$ for $5 \mathrm{~min}$, washed three times with tris(hydroxymethyl)aminomethane (TRIS) buffer (10 mM TRIS, $150 \mathrm{mM} \mathrm{NaCl}, \mathrm{pH} 7.2$ ) and diluted 10 times. Compounds were solubilized in TRIS buffer at 750, 500, 300 and $100 \mu \mathrm{M}$ and mixed with horse erythrocytes $(1: 1 \mathrm{v} / \mathrm{v})$. The mixture was incubated under continuous shaking for $1 \mathrm{~h}$ at $37^{\circ} \mathrm{C}$. Then, the tubes were centrifuged at $3500 \mathrm{~g}$ for $10 \mathrm{~min}, 80 \mu \mathrm{L}$ aliquots of the supernatant transferred to 100-well microplates (Bioscreen), diluted with $80 \mu \mathrm{L}$ water, and the absorbance measured at $540 \mathrm{~nm}$ (Bioscreen). Complete hemolysis was obtained by the addition of melittin at $100 \mu \mathrm{M}$ (Sigma-Aldrich Corporation, Madrid, Spain). The percentage of hemolysis $(H)$ was calculated using the equation: $H=100 \times$ $[(O p-O b) /(O m-O b)]$, where $O p$ is the density for a given compound concentration, $O b$ for the buffer, and $\mathrm{Om}$ for the melittin-positive control.

\subsection{Effect of Peptide Infiltration on Tobacco Leaves}

The lipopeptides were evaluated for their effect upon infiltration on tobacco leaves as described previously [60]. Peptide solutions of 50, 150 and $250 \mu \mathrm{M}$ were infiltrated $(100 \mu \mathrm{L})$ into the mesophylls of fully expanded tobacco leaves. Infiltrations were carried out in a single leaf, and for each peptide and dose, at least three leaves randomly distributed in different plants were infiltrated. Control infiltrations with water (negative control) or melittin (positive control) at the same molar concentration were performed. The appearance of symptoms on the leaves was followed for $48 \mathrm{~h}$ after infiltration and measured as a lesion diameter.

\subsection{Structural Characterization by NMR Spectroscopy}

The structure of lipopeptides BP389 and BP475 was determined by NMR spectroscopy. NMR spectra were acquired at the Serveis Tècnics de Recerca of the University of Girona with a Ultrashield $400 \mathrm{MHz}$ spectrometer equipped with an RT BBI. Each peptide was characterized with the following experiments: $1 \mathrm{D}^{1} \mathrm{H}-\mathrm{NMR}$; $2 \mathrm{D}^{1} \mathrm{H}-{ }^{1} \mathrm{H}$ TOCSY (mixing time $=80 \mathrm{~ms}$ ); $2 \mathrm{D}^{1} \mathrm{H}^{-1} \mathrm{H}$ NOESY (mixing time $=400 \mathrm{~ms}$ ); $2 \mathrm{D}^{1} \mathrm{H}-{ }^{13} \mathrm{C}$ multiplicity-edited HSQC; $2 \mathrm{D}^{1} \mathrm{H}_{-}{ }^{15} \mathrm{~N}$ HSQC; $2 \mathrm{D}^{1} \mathrm{H}_{-}^{-13} \mathrm{C}$ HSQC-TOCSY. Water suppression was achieved with excitation sculpting or Watergate scheme. NMR spectra were processed and analyzed using TopSpin 3.6.2. All experiments were conducted at $10^{\circ} \mathrm{C}$ using a shigemi tube calibrated for 
$\mathrm{D}_{2} \mathrm{O}$. Five milligrams of sample were dissolved in $400 \mu \mathrm{L}$ of $20 \mathrm{mM}$ phosphate buffer at $\mathrm{pH}$ 6.5 in $\mathrm{H}_{2} \mathrm{O} / \mathrm{D}_{2} \mathrm{O}$ (90:10) or in $400 \mu \mathrm{L}$ of this buffer containing 30\% of 2,2,2-trifluoroethanol$\mathrm{d}_{3}$ to induce the formation of the secondary structure. From NMR assignments, the structural analysis was achieved with Chemical Shift Index 3.0 web server [61,62].

\section{Conclusions}

In summary, we designed and synthesized D-amino-containing lipopeptides derived from BP100. These lipopeptides displayed an improved biological activity profile compared to their L-counterparts. Remarkably, replacement of the L-Phe at position 4 with its enantiomer provided less hemolytic lipopeptides. The best derivatives-BP475 (D-F ${ }^{4}$ $\mathrm{K}^{10}\left(\mathrm{COC}_{3} \mathrm{H}_{7}\right)$ and BP485 $\left(\mathrm{C}_{3} \mathrm{H}_{7} \mathrm{CO}-\mathrm{D}-\mathrm{F}^{4}\right)$ - exhibited high antimicrobial activity (MIC between 0.8 and $6.2 \mu \mathrm{M})$ together with a low hemolysis ( 0 and $24 \%$ at $250 \mu \mathrm{M}$, respectively). In addition, the results from the NMR experiments of BP475 demonstrate the importance of a C-terminal $\alpha$-helix in the activity of these lipopeptides. This study provides tools for the design of new agents to control plant pathogens.

Supplementary Materials: The following are available online at https:/ /www.mdpi.com/article/ 10.3390/ijms22126631/s1: biological activity of lipopeptides; Synthesis of lipopeptides; HPLC of crude and purified lipopeptides; ESI-MS and HRMS of purified lipopeptides; NMR experiments of lipopeptides BP389 and BP475.

Author Contributions: Conceptualization, E.B., A.B., E.M., M.P. and L.F.; methodology, À.O., L.M., G.R.-L., A.T.-C. and S.G.-C.; software, À.O. and G.R.-L.; validation, À.O., G.R.-L., E.B., A.B., E.M., M.P. and L.F.; formal analysis, À.O., G.R.-L., L.M., S.G.-C., E.B., A.B, E.M., M.P. and L.F.; investigation, À.O., L.M., G.R.-L., A.T.-C. and S.G.-C.; resources, E.B., A.B., E.M., M.P. and L.F.; data curation, E.B., A.B., E.M., M.P. and L.F.; writing-original draft preparation, À.O., G.R.-L., M.P. and L.F.; writing-review and editing, À.O., G.R.-L., L.M., S.G.-C., E.B., A.B., E.M., M.P. and L.F.; visualization, E.B., A.B., E.M., M.P. and L.F.; supervision, E.B., A.B, E.M., M.P. and L.F.; project administration, E.B., A.B., E.M., M.P. and L.F.; funding acquisition, E.B., A.B., E.M., M.P. and L.F. All authors have read and agreed to the published version of the manuscript.

Funding: This research was funded by MINECO/FEDER, UE, grant number AGL2015-69876-C2-2-R, by Universitat de Girona, grant number MPCUdG2016/038, and by MCIU/AEI/FEDER, UE, grant number RTI2018-099410-B-C22.

Institutional Review Board Statement: Not applicable.

Informed Consent Statement: Not applicable.

Data Availability Statement: Samples of the compounds are available from the authors.

Acknowledgments: The authors acknowledge the Serveis Tècnics de Recerca of the University of Girona for the mass spectrometry analysis.

Conflicts of Interest: The authors declare no conflict of interest.

\section{References}

1. Department of Economic and Social Affairs, United Nations. World Population Prospects 2019. Available online: https: / / population.un.org/wpp/ (accessed on 21 May 2021).

2. Oerke, E. Crop losses to pests. J. Agric. Sci. 2006, 144, 31-43. [CrossRef]

3. Mansfield, J.; Genin, S.; Magori, S.; Citovsky, V.; Sriariyanum, M.; Ronald, P.; Dow, M.; Verdier, V.; Beer, S.V.; Machado, M.A.; et al. Top 10 plant pathogenic bacteria in molecular plant pathology. Mol. Plant Pathol. 2012, 13, 614-629. [CrossRef] [PubMed]

4. Keymanesh, K.; Soltani, S.; Sardari, S. Application of antimicrobial peptides in agriculture and food industry. World J. Microbiol. Biotechnol. 2009, 25, 933-944. [CrossRef]

5. Montesinos, E.; Badosa, E.; Cabrefiga, J.; Planas, M.; Feliu, L.; Bardaji, E. Antimicrobial Peptides for Plant Disease Control—From Discovery to Application. In Small Wonders: Peptides for Disease Control; Rajasekaran, K., Cary, J.W., Jaynes, J.M., Montesinos, E., Eds.; ACS Symposium Series; American Chemical Society: Washington, DC, USA, 2012; pp. 235-262.

6. De Souza Candido, E.; de Silva Cardoso, M.H.; Sousa, D.A.; Viana, J.C.; de Oliveira-Júnior, N.G.; Miranda, V.; Franco, O.L. The use of versatile plant antimicrobial peptides in agribusiness and human health. Peptides 2014, 55, 65-78. [CrossRef] [PubMed]

7. Huan, Y.; Kong, Q.; Mou, H.; Yi, H. Antimicrobial peptides: Classification, design, application and research progress in multiple fields. Front. Microbiol. 2020, 11, 582779. [CrossRef] 
8. Ageitos, J.M.; Sánchez-Pérez, A.; Calo-Mata, P.; Villa, T.G. Antimicrobial peptides (AMPs): Ancient compounds that represent novel weapons in the fight against bacteria. Biochem. Pharmacol. 2017, 133, 117-138. [CrossRef]

9. Hollmann, A.; Martinez, M.; Maturana, P.; Semorile, L.C.; Maffia, P.C. Antimicrobial Peptides: Interaction with model and biological membranes and synergism with chemical antibiotics. Front. Chem. 2018, 6, 204. [CrossRef] [PubMed]

10. Kumar, P.; Kizhakkedathu, J.N.; Straus, S.K. Antimicrobial peptides: Diversity, mechanism of action and strategies to improve the activity and biocompatibility in vivo. Biomolecules 2018, 8, 4. [CrossRef]

11. Feijó Corrêa, J.A.; Gonçalves Evangelista, A.; de Melo Nazareth, T.; Bittencourt Luciano, F. Fundamentals on the molecular mechanism of action of antimicrobial peptides. Materialia 2019, 8, 100494. [CrossRef]

12. Browne, K.; Chakraborty, S.; Chen, R.; Willcox, M.D.; Black, D.S.; Walsh, W.R.; Kumar, N. A new era of antibiotics: The clinical potential of antimicrobial peptides. Int. J. Mol. Sci. 2020, 21, 7047. [CrossRef]

13. Magana, M.; Pushpanathan, M.; Santos, A.L.; Leanse, L.; Fernandez, M.; Ioannidis, A.; Giulianotti, M.A.; Apidianakis, Y.; Bradfute, S.; Ferguson, A.L.; et al. The value of antimicrobial peptides in the age of resistance. Lancet Infect. Dis. 2020, 20, e216-e230. [CrossRef]

14. Mahlapuu, M.; Björn, C.; Ekblom, J. Antimicrobial peptides as therapeutic agents: Opportunities and challenges. Crit. Rev. Biotechnol. 2020, 40, 978-992. [CrossRef]

15. Gomes, B.; Augusto, M.T.; Felício, M.R.; Hollmann, A.; Franco, O.L.; Gonçalves, S.; Santos, N.C. Designing improved active peptides for therapeutic approaches against infectious diseases. Biotechnol. Adv. 2018, 36, 415-429. [CrossRef] [PubMed]

16. Ciumac, D.; Gong, H.; Hu, X.; Lu, J.R. Membrane targeting cationic antimicrobial peptides. J. Colloid Interface Sci. 2019, 537, 163-185. [CrossRef] [PubMed]

17. Hazam, P.K.; Goyal, R.; Ramakirshnan, V. Peptide based antimicrobials: Design strategies and therapeutic potential. Prog. Biophys. Mol. Biol. 2019, 142, 10-22. [CrossRef]

18. Liu, Y.; Shi, J.; Tong, Z.; Jia, Y.; Yang, B.; Wang, Z. The revitalization of antimicrobial peptides in the resistance area. Pharmacol. Res. 2021, 163, 105276. [CrossRef] [PubMed]

19. Jerala, R. Synthetic lipopeptides: A novel class of anti-infectives. Expert Opin. Investig. Drugs 2007, 16, 1159-1169. [CrossRef] [PubMed]

20. Patel, S.; Ahmed, S.; Eswari, J.S. Therapeutic cyclic lipopeptides mining from microbes: Latest strides and hurdles. World J. Microbiol. Biotechnol. 2015, 31, 1177-1193. [CrossRef]

21. Zhao, H.; Shao, D.; Jiang, C.; Shi, J.; Li, Q.; Huang, Q.; Rajoka, M.S.R.; Yang, H.; Jin, M. Biological activity of lipopeptides from Bacillus. Appl. Microbiol. Biotechnol. 2017, 101, 5951-5960. [CrossRef] [PubMed]

22. Malina, A.; Shai, Y. Conjugation of fatty acids with different lengths modulates the antibacterial and antifungal activity of a cationic biologically inactive peptide. Biochem. J. 2005, 390, 695-702. [CrossRef]

23. Mandal, S.M.; Barbosa, A.E.; Franco, O.L. Lipopeptides in microbial infection control: Scope and reality for industry. Biotechnol. Adv. 2013, 31, 338-345. [CrossRef]

24. Meena, K.R.; Kanwar, S.S. Lipopeptides as the antifungal and antibacterial agents: Applications in food safety and therapeutics. BioMed Res. Int. 2015, 473050. [CrossRef] [PubMed]

25. Malmsten, M. Interactions of antimicrobial peptides with bacterial membranes and membrane components. Curr. Top. Med. Chem. 2016, 16, 16-24. [CrossRef]

26. Vilà, S.; Badosa, E.; Montesinos, E.; Planas, M.; Feliu, L. Synthetic cyclolipopeptides selective agaisnt microbial, plant and animal cell targets by incorporation of D-amino acids or histidine. PLoS ONE 2016, 11, e0151639. [CrossRef]

27. Koh, J.-J.; Lin, S.; Beuerman, R.W.; Liu, S. Recent advances in synthetic lipopeptides as anti-microbial agents: Designs and synthetic approaches. Amino Acids 2017, 49, 1653-1677. [CrossRef]

28. Avitabile, C.; D'Andrea, L.D.; D'Aversa, E.; Milani, R.; Gambari, R.; Romanelli, A. Effect of acylation on the antimicrobial activity of temporin B analogues. ChemMedChem 2018, 13, 1549-1554. [CrossRef] [PubMed]

29. Sim, J.-Y.; Kim, S.; Lee, J.; Lim, H.; Kim, H.H.; Park, Z.-Y.; Kim, J.I. A significantly enhanced antibacterial spectrum of Denantiomeric lipopeptide bactenecin. Biochem. Biophys. Res. Commun. 2019, 514, 497-502. [CrossRef]

30. Albada, B. Tuning Activity of Antimicrobial Peptides by Lipidation. In Health Consequences of Microbial Interactions with Hydrocarbons, Oils, and Lipids: Handbook of Hydrocarbon and Lipid Microbiology; Goldfine, H., Ed.; Springer: Cham, Switzerland, 2020; pp. 317-334. [CrossRef]

31. Chu-Kung, A.F.; Nguyen, R.; Bozzelli, K.N.; Tirrell, M. Chain length dependence of antimicrobial peptide-fatty acid conjugate activity. J. Colloid Interface Sci. 2010, 345, 160-167. [CrossRef]

32. Güell, I.; Cabrefiga, J.; Badosa, E.; Ferre, R.; Talleda, M.; Bardají, E.; Planas, M.; Feliu, L.; Montesinos, E. Improvement of the efficacy of linear undecapeptides against plant-pathogenic bacteria by incorporation of D-amino acids. Appl. Environ. Microbiol. 2011, 77, 2667-2675. [CrossRef] [PubMed]

33. Huang, Y.; He, L.; Li, G.; Zhai, N.; Jiang, H.; Chen, Y. Role of helicity of $\alpha$-helical antimicrobial peptides to improve specificity. Protein Cell 2014, 5, 631-642. [CrossRef]

34. Ong, Z.Y.; Wiradharma, N.; Yang, Y.Y. Strategies employed in the design and optimization of synthetic antimicrobial peptide amphiphiles with enhance therapeutic potentials. Adv. Drug Deliv. Rev. 2014, 78, 28-45. [CrossRef]

35. Li, H.; Anuwongcharoen, N.; Malik, A.A.; Prachayasittikul, V.; Wikberg, J.E.S.; Nantasenamat, C. Roles of D-amino acids on the bioactivity of host defense peptides. Int. J. Mol. Sci. 2016, 17, 1023. [CrossRef] [PubMed] 
36. Xie, J.; Zhao, Q.; Li, S.; Yan, Z.; Li, J.; Li, Y.; Mou, L.; Zhang, B.; Yang, W.; Miao, X.; et al. Novel antimicrobial peptide CPF-C1 analogs with superior stabilities and activities against multidrug-resistant bacteria. Chem. Biol. Drug Des. 2017, 90, 690-702. [CrossRef]

37. Jia, F.; Wang, J.; Peng, J.; Zhao, P.; Kong, Z.; Wang, K.; Yan, W.; Wang, R. D-Amino acid substitution enhances the stability of antimicrobial peptide polybia-CP. Acta Biochim. Biophys. Sin. 2017, 49, 916-925. [CrossRef]

38. Konai, M.M.; Adhikary, U.; Haldar, J. Design and solution-phase synthesis of membrane-targeting lipopeptides with selective antibacterial activity. Chemistry 2017, 23, 12853-12860. [CrossRef] [PubMed]

39. Xie, J.; Li, Y.; Li, J.; Yan, Z.; Wang, D.; Guo, X.; Zhang, J.; Zhang, B.; Mou, L.; Yang, W.; et al. Potent effects of amino acid scanned antimicrobial peptide Feleucin-K3 analogues against both multidrug-resistant strains and biofilms of Pseudomonas aeruginosa Amino Acids 2018, 50, 1471-1483. [CrossRef]

40. Topman, S.; Tamir-Ariel, D.; Bochnic-Tamir, H.; Stern Bauer, T.; Shafir, S.; Burdman, S.; Hayouka, Z. Random peptide mixtures as new crop protection agents. Microb. Biotechnol. 2018, 11, 1027-1036. [CrossRef] [PubMed]

41. Casciaro, B.; Cappiello, F.; Loffredo, M.R.; Ghirga, F.; Mangoni, M.L. The potential of frog skin peptides for anti-infective therapies: The case of Esculentin-1a(1-21) $\mathrm{NH}_{2}$. Curr. Med. Chem. 2020, 27, 1405-1419. [CrossRef]

42. Avrahami, D.; Shai, Y. Bestowing antifungal and antibacterial activities by lipophilic acid conjugation to D,L-amino acid-containing antimicrobial peptides: A plausible mode of action. Biochemistry 2003, 42, 14946-14956. [CrossRef] [PubMed]

43. Makovitzki, A.; Shai, Y. pH-dependent antifungal lipopeptides and their plausible mode of action. Biochemistry 2005, 44, 9775-9784. [CrossRef]

44. Rosenfeld, Y.; Lev, N.; Shai, Y. Effect of the hydrophobicity to net positive charge ratio on antibacterial and anti-endotoxin activities of structurally similar antimicrobial peptides. Biochemistry 2010, 49, 853-861. [CrossRef]

45. Lee, J.; Kim, S.; Sim, J.Y.; Lee, D.; Kim, H.H.; Hwang, J.S.; Lee, D.G.; Park, Z.Y.; Kim, J.I. A potent antibacterial activity of new short D-enantiomeric lipopeptide against multi drug resistant bacteria. Biochim. Biophys. Acta Biomembr. 2019, 1861, 34-42. [CrossRef]

46. Oliveras, A.; Baro, A.; Montesinos, L.; Badosa, E.; Montesinos, E.; Feliu, L.; Planas, M. Antimicrobial activity of linear lipopeptides derived from BP100 towards plant pathogens. PLOS ONE 2018, 13, e0201571. [CrossRef] [PubMed]

47. Tengel, T.; Sethson, I.; Francis, M.S. Conformational analysis by CD and NMR spectroscopy of a peptide encompassing the amphipathic domain of YopD from Yersinia. Eur. J. Biochem. 2002, 15, 3659-3668. [CrossRef] [PubMed]

48. Di Grazia, A.; Cappiello, F.; Cohen, H.; Casciaro, B.; Luca, V.; Pini, A.; Di, Y.P.; Shai, Y.; Mangoni, M.L. D-Amino acids incorporation in the frog skin-derived peptide esculentin-1a(1-21) $\mathrm{NH}_{2}$ is beneficial for its multiple functions. Amino Acids 2015, 47, 2505-2519. [CrossRef]

49. Makovitzki, A.; Avrahamai, D.; Shai, Y. Ultrashort antibacterial and antifungal lipopeptides. Proc. Natl. Acad. Sci. USA 2006, 103, 15997-16002. [CrossRef] [PubMed]

50. Mangoni, M.L.; Shai, Y. Short native antimicrobial peptides and engineered ultrashort lipopeptides: Similarities and differences in cell specificities and modes of action. Cell. Mol. Life Sci. 2011, 68, 2267-2280. [CrossRef]

51. Laverty, G.; McLaughlin, M.; Shaw, C.; Gorman, S.P.; Gilmore, B.F. Antimicrobial activity of short, synthetic cationic lipopeptides. Chem. Biol. Drug Des. 2010, 75, 563-569. [CrossRef]

52. Greber, K.E.; Dawgul, M.; Kamysz, W.; Sawicki, W. Cationic net charge and counter ion type as antimicrobial activity determinant factors of short lipopeptides. Front. Microbiol. 2017, 8, 123. [CrossRef]

53. Blondelle, S.E.; Lohner, K. Combinatorial libraries: A tool to design antimicrobial and antifungal peptide analogues having lytic specificities for structure-activity relationship studies. Biopolymers 2000, 55, 74-87. [CrossRef]

54. Oh, D.; Shin, S.Y.; Lee, S.; Kang, J.H.; Kim, S.D.; Ryu, P.D.; Hahm, K.S.; Kim, Y. Role of the hinge region and the tryptophan residue in the synthetic antimicrobial peptides, cecropin A(1-8)-magainin 2(1-12) and its analogues, on their antibiotic activities and structures. Biochemistry 2000, 39, 11855-11864. [CrossRef] [PubMed]

55. Makovitzki, A.; Viterbo, A.; Brotman, Y.; Chet, I.; Shai, Y. Inhibition of fungal and bacterial plant pathogens in vitro and in planta with ultrashort cationic lipopeptides. Appl. Environ. Microbiol. 2007, 73, 6629-6636. [CrossRef] [PubMed]

56. Zamora-Carreras, H.; Strandberg, E.; Muhlhauser, P.; Burch, J.; Wadhwani, P.; Jimenez, M.A.; Bruix, M.; Ulrich, A.S. Alanine scan and ${ }^{2} \mathrm{H}$ NMR analysis of the membrane-active peptide BP100 point to a distinct carpet mechanism of action. Biochim. Biophys. Acta 2016, 1858, 1328-1338. [CrossRef]

57. Kaiser, E.; Colescott, R.L.; Bossinger, C.D.; Cook, P. Color test for detection of free terminal amino groups in the solid-phase synthesis of peptides. Anal. Biochem. 1970, 34, 595-598. [CrossRef]

58. Hazel, W.J.; Civerolo, E.L. Procedures for growth and inoculation of Xanthomonas fragariae, causal organism of angular leaf spot of strawberry. Plant Dis. 1980, 64, 178-181. [CrossRef]

59. Badosa, E.; Ferre, R.; Planas, M.; Feliu, L.; Besalu, E.; Cabrefiga, J.; Bardaji, E.; Montesinos, E. A library of linear undecapeptides with bactericidal activity against phytopathogenic bacteria. Peptides 2007, 28, 2276-2285. [CrossRef] [PubMed]

60. Badosa, E.; Moiset, G.; Montesinos, L.; Talleda, M.; Bardají, E.; Feliu, L.; Planas, M.; Montesinos, E. Derivatives of the antimicrobial peptide BP100 for expression in plant systems. PLoS ONE 2013, 8, e85515. [CrossRef]

61. Berjanskii, M.V.; Wishart, D.S. A simple method to predict protein flexibility using secondary chemical shifts. J. Am. Chem. Soc. 2005, 127, 14970-14971. [CrossRef]

62. Hafsa, N.E.; Arndt, D.; Wishart, D.S. CSI 3.0: A web server for identifying secondary and super-secondary structure in proteins using NMR chemical shifts. Nucleic Acids Res. 2015, 43, W370-W377. [CrossRef] 